\title{
Idiopathic Intracranial Hypertension: Diagnosis and Therapeutic Approach
}

\section{İdiyopatik Intrakraniyal Hipertansiyon: Tanı ve Tedavi Yaklaşımı}

\author{
Nihan Hande Akçakaya ${ }^{1}$, Mehmet Osman Akçakaya ${ }^{2}$, Altay Sencer ${ }^{3}$, Zuhal Yapıcı ${ }^{4}$ \\ ${ }^{1}$ Istanbul University Aziz Sancar Institute of Experimental Medicine, Department of Genetics, Istanbul, Turkey \\ 2Liv Hospital, Clinic of Neurosurgery, Istanbul, Turkey \\ 3/stanbul University Istanbul Faculty of Medicine, Department of Neurosurgery, Istanbul, Turkey \\ ${ }^{4}$ Istanbul University Istanbul Faculty of Medicine, Department of Neurology, Istanbul, Turkey
}

\begin{abstract}
Idiopathic intracranial hypertension (IIH) is a condition of increased intracranial pressure without a secondary etiology. IIH is seen frequently in young and obese women. Headache, vision problems, and pulsatile tinnitus are the most common symptoms that lead patients to physicians. IIH requires a multidisciplinary approach because it could create permanent morbidity and its treatment plan should be individualized for each patient. The aim of this review was to provide an updated overview of IIH's pathogenesis, diagnostic criteria, and treatment strategies.
\end{abstract}

Keywords: Idiopathic intracranial hypertension, pseudotumor cerebri, primary pseudotumor cerebri, optic nerve compartment syndrome, review

\section{$\ddot{O} z$}

İdiyopatik intrakraniyal hipertansiyon (İİH) sekonder bir nedene bağlı olmayan kafa içi basınç artışıdır. Sıklıkla genç ve obez kadınlarda görülür. Baş ağrısı, görme problemleri ve pulsatil kulak çınlaması hastaları en çok hekime götüren şikayetlerdir. İİH heterojen bulgu ve belirtileri nedeniyle aile hekimlerini ve birçok branşı birlikte ilgilendirmektedir. Tedavisi gecikirse kalıcı morbidite yaratan bu hastalıkta her olgu için kişiye özgü bir tedavi planlanmalıdır. Bu yazıda son yayınlar çerçevesinde İIH'nin etiyopatogenezi ile birlikte tanı ve tedavisi gözden geçirilmiştir.

Anahtar Kelimeler: İdiyopatik intrakraniyal hipertansiyon, psödotümör serebri, primer psödotümör serebri, optik sinir kompartman sendromu, derleme

\section{Introduction}

Idiopathic intracranial hypertension (IIH) is characterized by increased intracranial pressure of unknown etiology (not due to a secondary cause) with normal cerebrospinal fluid (CSF) composition. The annual incidence of IIH is approximately $3 / 100,000$ persons and it is usually seen in young obese women $(1,2)$. The major morbidities are headache and vision loss if the disease cannot be diagnosed or the treatment is delayed (3).
The synonymous/interchangeable use of pseudotumor cerebri by IIH is not correct, because pseudotumor cerebri includes secondary causes of intracranial hypertension except space occupying lesions. At the present time, $\mathrm{IIH}$ is referred to as primary pseudotumor cerebri (4). IIH is increased intracranial pressure of unknown etiology despite all examinations. The terms "benign intracranial hypertension, meningeal hydrops and serous meningitis are no longer used.

Patients with IIH are admitted to neurologists, ophthalmologists, ear-nose-throat specialists, neurosurgeons, and

Address for Correspondence/Yazışma Adresi: Nihan Hande Akçakaya MD, Istanbul University Aziz Sancar Institute of Experimental Medicine, Clinic of Genetics, Istanbul, Turkey

Phone: +90 5335413633 E-mail: nhakcakaya@gmail.com

Received/Geliş Tarihi: 05.12.2015 Accepted/Kabul Tarihi: 08.05.2016

${ }^{\circ}$ Copyright 2017 by Turkish Neurological Society

Turkish Journal of Neurology published by Galenos Publishing House. 
family physicians with heterogeneous signs and symptoms. In this article, we aimed to review the current diagnosis and treatment of IIH (primary pseudotumor cerebri) within the context of recent publications.

\section{Signs and Symptoms}

Headache $(92 \%)$ and transient vision loss $(72 \%)$ are the most common symptoms of IIH $(5,6)$. The headache has frontal, retroorbital location, and is usually throbbing in nature or with pressure sensation (7). The daily persistent headache is characterized by worsening during activities such as coughing and standing (8). Allodynia is a common $(50 \%)$ symptom in patients with headaches and migrainous features may be seen (9). The typical allodynia with facial nerve distribution and retroocular pain with eye movements were defined as distinguishing symptoms from other types of headache $(5,9)$.

Except for anecdotal cases, papilledema is observed in all patients with IIH and can be detected rarely without headache $(10,11)$. If left untreated, it may cause blindness due to progressive vision loss and optic atrophy (3). The risk factors for the development of vision loss are as follows: male sex (12), puberty $(13,14)$, patients aged 40 years or older $(15)$, sleep apnea syndrome (16), black race (17), and morbid obesity (18). Absence of headache, and accompanying hypertension and anemia are also associated with poor prognosis $(12,19,20)$. Transient vision loss, blurred vision and photopsia are considered to be associated with papilledema.

There are also reported cases with unilateral or asymmetric papilledema $(21,22)$. The mechanical pressure on the pituitary gland due to long-term increased intracranial pressure causes "empty sella" syndrome. Displacement of optic chiasma and optic nerve in the empty cella may cause vision impairment in patients. It has been suggested that papilledema can be asymmetric if this displacement occurs asymmetrically (23).

The major visual field defects are blind spot enlargement, cecocentral scotoma, and concentric contractions. Blind spot enlargement is a typical defect that occurs due to optic disc swelling and displacement of peripapillary retinal receptors (choroidal folding) as a result of increased intracranial pressure. Inferior nasal visual field loss is another common visual field defect that occurs due to compression and resulting infarction of nerve axons at disk level (3).

The patients may consult ear-nose-throat specialists with pulsatile tinnitus, fullness in the ears, inability to hear lowfrequency sounds, vertigo $(24,25)$, and spontaneous otorrhea or rhinorrhea $(26,27)$. Although spontaneous otorrhea and rhinorrhea have many causes, IIH should be kept in mind especially in overweight women with a body mass index $>30 \mathrm{~kg} / \mathrm{m}^{2}$ (28). Diplopia, nausea, neck pain or back pain are other symptoms that can be seen in IIH $(7,29)$.

\section{Diagnostic Criteria and Differential Diagnosis}

IIH diagnostic criteria were revised in 2014 in order to better distinguish secondary causes (Table 1) (30). All factors that can lead to an increase in intracranial pressure must be investigated for a diagnosis of IIH. Detailed medical history and further evaluation is important for an appropriate treatment approach. Associated conditions in the differential diagnosis are summarized in Table $2(31,32)$.

The normal CSF opening pressure measured in the lateral decubitus position is $180-200 \mathrm{mmH}_{2} \mathrm{O}$. In the International Classification of Headache Disorders published by the International Headache Society (IHS) in 2013, a CSF opening pressure of over $250 \mathrm{mmH}_{2} \mathrm{O}$ in patients with headaches was defined as a diagnostic criterion for IIH (7). The IHS criteria do not cover patients with a CSF opening pressure of $200-250 \mathrm{mmH}_{2} \mathrm{O}$ and patients without headaches. In patients with a CSF opening pressure of 200-250 $\mathrm{mmH}_{2} \mathrm{O}$, at least one accompanying condition among pulsatile tinnitus, sixth cranial nerve palsy, papilledema, transverse venous sinus stenosis on magnetic resonance (MR) venography, partial empty sella or distention of the perioptic subarachnoid space on cranial MR imaging (MRI) was defined sufficient for the diagnosis of IIH (Table 1) (30). CSF opening pressure measurement should be performed in the lateral decubitus position prior to use of sedative drugs or initiation of pressure lowering treatment (7). CSF biochemistry and cytology should be normal.

The differential diagnosis of pseudopapilledema causes such as optic disc drusen and elevated optic nerve in hyperopia, and true papilledema must be performed by an experienced neuro-ophthalmologist. Blurring of optic nerve margins, loss of spontaneous venous pulsation, venous engorgement, elevation of optic disc, peripapillary hemorrhage and exudate or optic nerve layer infarcts are suggestive of true papilledema (Figure 1). Blood pressure measurements should be performed in patients

\section{Table 1. Modified Dandy criteria for the diagnosis of} idiopathic intracranial hypertension

1. Signs and symptoms of increased intracranial pressure 2. Absence of localizing findings on neurologic examination

3. Absence of deformity, displacement or obstruction of the ventricular system and otherwise normal neurodiagnostic studies, except for evidence of increased CSF pressure $(>200$ $\mathrm{mmH}_{2} \mathrm{O}$ ); abnormal neuroimaging except for empty sella turcica, optic nerve sheath with filled CSF spaces, and smoothwalled non-flow-related venous sinus stenosis or collapse should lead to another diagnosis

4. Awake and alert

5. No other cause of increased intracranial pressure present For CSF opening pressure of $200-250 \mathrm{mmH}_{2} \mathrm{O}$ required at least one of the following:

Pulse synchronous tinnitus,

$6^{\text {th }}$ palsy,

Frisen grade 2 papilledema,

Echography for drusen-negative and no other disc anomalies mimicking disc edema present.

Magnetic resonance venography with lateral sinus collapse/ stenosis preferably using auto-triggered elliptic centric-ordered technique.

Partially empty sella on coronal or sagittal views and optic nerve sheaths with filled CSF spaces next to the globe on T2weighted axial scans.

CSF: Cerebrospinal fluid 
Table 2. Differential diagnosis of idiopathic intracranial hypertension

1. Estrogen-related conditions:

- Oral contraceptives,

- Pregnancy,

Polycystic ovary syndrome.

2. Intracranial venous flow pathology:

- Congenital abnormalities that prevent venous flow,

- Dural venous sinus compression or obstruction,

Extra-cranial pathologies that prevent cranial venous flow,

- Venous sinus thrombosis.

3. Hematologic pathologies:

- Anemia (e.g., iron deficiency, pernicious, aplastic),

- Leukemia,

- Myeloma,

- Polycythemia,

- Platelet or factor abnormalities,

- Peripheral neuropathy, organomegaly, endocrinopathy,

monoclonal gammopathy (POEMS) syndrome

4. Endocrine pathologies:

- Thyroid (hypothyroidism, thyroid replacement therapy),

- Adrenal (hyperadrenalism, Cushing's syndrome, Addison's disease),

- Parathyroid (hypoparathyroidism,

pseudohypoparathyroidism),

- Pituitary (acromegaly, growth hormone replacement therapy),

- Turner syndrome,

- Others

5. Infections:

Otitis media, mastoiditis,

- Non-specific viral infections,

- Lyme disease,

- Chronic meningitis (syphilis, brucellosis, cryptococcus),

Poliomyelitis, Guillain-Barré syndrome,

- Other viral infections (varicella, enterovirus 71),

- Other bacterial infections (frontal/paranasal sinusitis,

gastroenteritis, typhoid)

6. Head trauma

7. Nutritional pathologies:

- Vitamin D deficiency,

- Malnutrition,

- Vitamin A deficiency and excess

8. Drugs and chemicals:

- Steroids,

- Tetracyclines,

- Nalidixic acid,

- Other agents (danazol, lithium carbonate, perhexiline maleate, amiodarone, penicillin, ciprofloxacin, nitrofurantoin, sulfamethoxazole, mesalamine)

9. Other diseases:

- Systemic lupus erythematosus,

- Behcet's disease,

- Renal disease,

- Cardiac and respiratory diseases,

Sleep disorders,

Psychiatric disorders (depression, bulimia),

- Enzyme deficiencies (galactosemia, 11-beta-hydroxylase deficiency, alpha-chymotrypsin deficiency)

The references of the Table are mentioned in the text. with papilledema to rule out malignant hypertension, and these patients should be referred for neuroimaging regarding intracranial pathologies in the differential diagnosis. Most of patients with IIH who have papilledema are not aware of the contraction in the visual field, and visual field examination and fundus imaging by automated perimetry should be performed to monitor the disease.

The main neuroimaging findings that may accompany IIH are empty sella (70\%), distention (45\%), and tortuosity (40\%) of the perioptic subarachnoid space, flattening of the posterior sclera $(80 \%)$, protrusion of optic nerve papillae into vitreous, and transverse sinus stenosis (90\%) (Figure 2, 3) $(4,7,30,33,34)$. It should not be forgotten that these findings are not specific to $\mathrm{IIH}$ and other pathologies that may cause these findings must

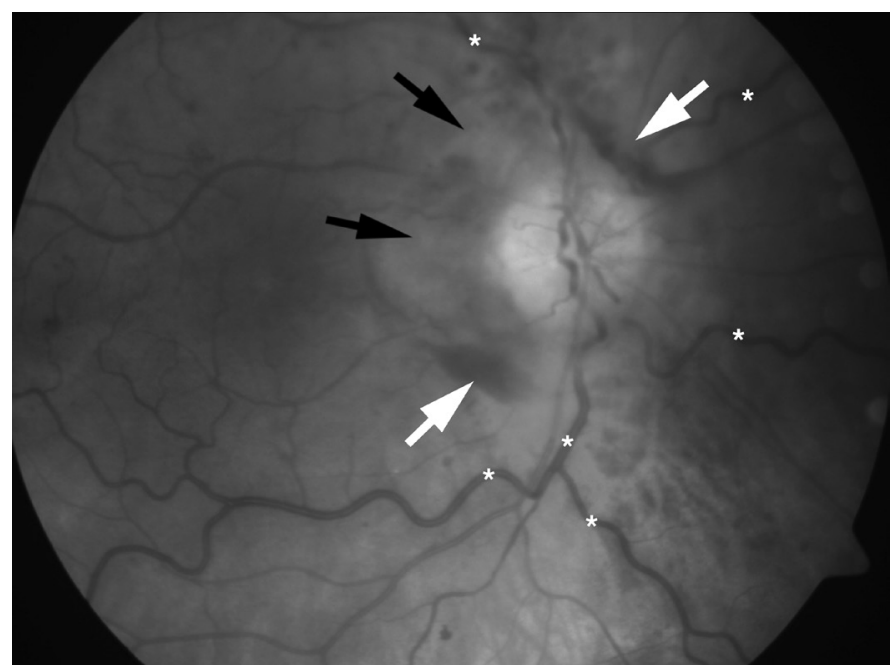

Figure 1. Papilledema in a patient with idiopathic intracranial hypertension: Blurring of optic nerve margins and elevation of optic disc, retinal venous engorgement $(*)$, peripapillary hemorrhage (white arrows) and exudate (black arrows).

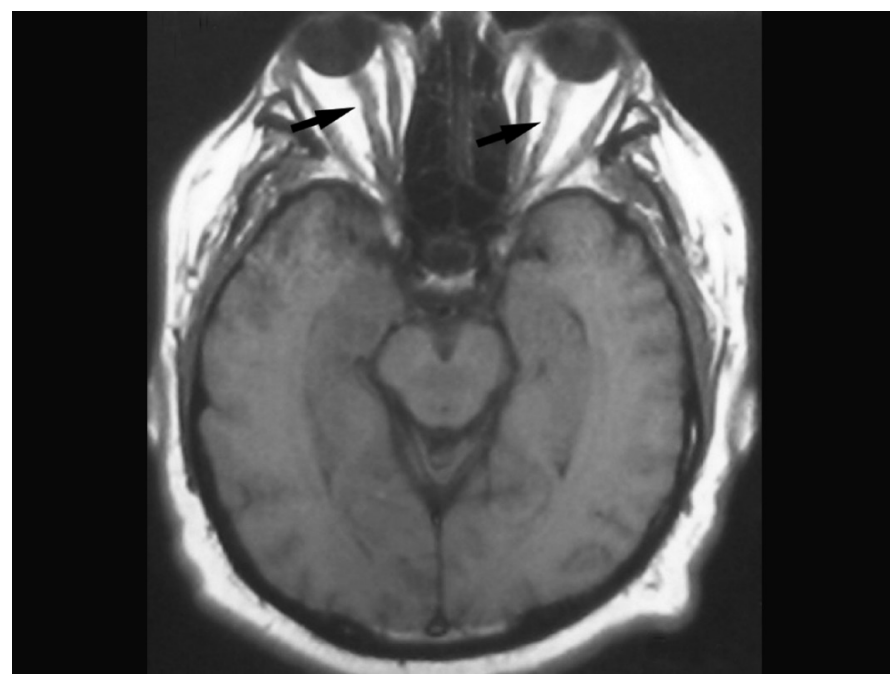

Figure 2. Bilateral optic nerve tortuosity (arrows) on axial T1-weighted magnetic resonance imaging of a patient with idiopathic intracranial hypertension. 
be evaluated. MRI examination should include intravenous contrast-enhanced cranial and orbital MRI and MR venography in order to exclude possible space occupying lesions and infectious pathologies. Fat suppression sequences will provide better distinguishing of orbital and optic nerve pathologies. CSF opening pressure should be measured after making sure that there is no intracranial space-occupying lesion in patients with papilledema using neuroimaging.

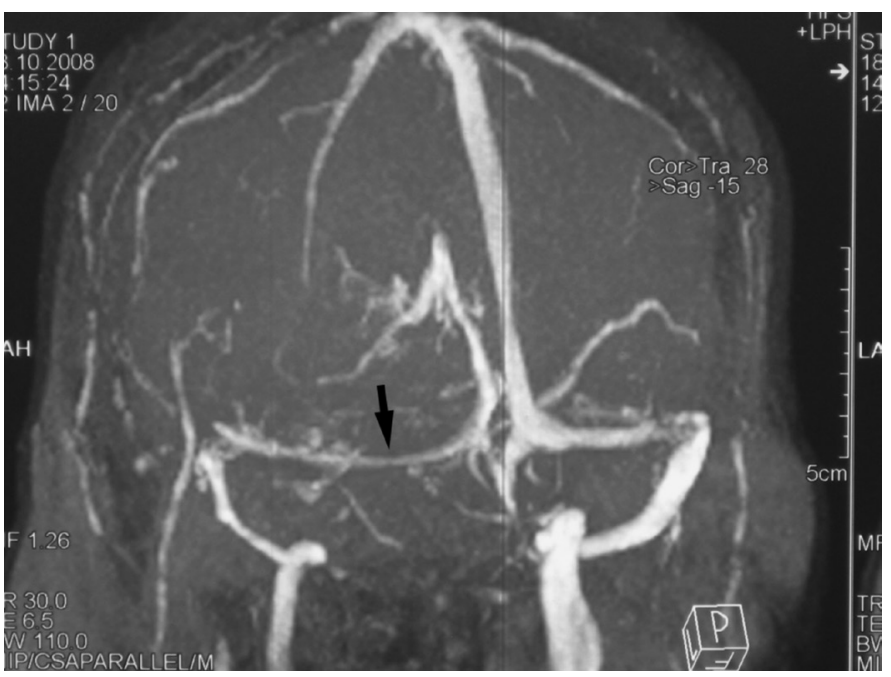

Figure 3. Left transverse sinus stenosis (arrow) on magnetic resonance venography of a patient with idiopathic intracranial hypertension.

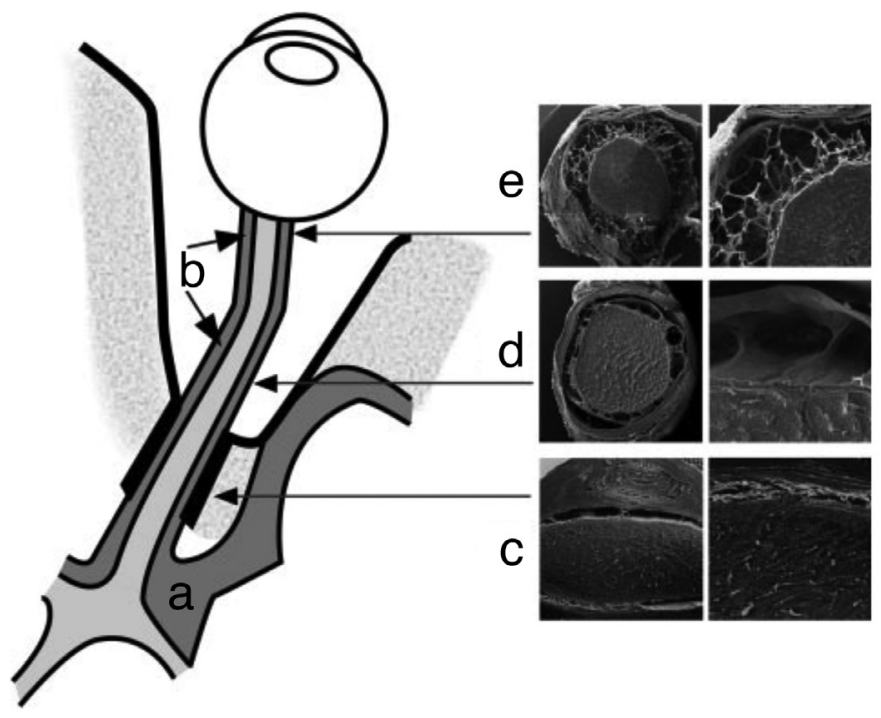

Figure 4. Schematic representation of the cerebrospinal fluid (CSF) spaces surrounding the optic chiasm (intracranial CSF space) (a) and the optic nerve (intraorbital CSF space) (b). CSF flows from intracranial subarachnoid space (a) into the orbita (b). The CSF space in the canalicular region (c) is the narrowest subarachnoid space surrounding the optic nerve. The intraorbital segment of the subarachnoid space is characterized by septae (d) and the retrobulbar segment is characterized by small trabeculae (e). Due to the CSF volume gradient, the direction of flow is directed from the intracranial subarachnoid space to the intraorbital subarachnoid space.
All patients should undergo a basic examination for pathologies listed in the differential diagnosis (Table 2) by evaluation of blood pressure, body temperature, fasting blood glucose, blood count, and serum biochemistry including liver enzymes, and renal function parameters $(31,32)$. However, medical history will guide further investigation.

\section{Etiopathogenesis}

IIH is believed to result from irregularities of CSF production, distribution and absorption, however etiopathogenesis still remains unclear. Parenchymal edema, increased cerebral blood flow, increased CSF production, and obstruction of venous drainage have been suggested as causes (32).

Increased intracranial pressure in cases of disturbances in the hypothalamic-pituitary-adrenal axis (Addison's disease, Cushing's syndrome, corticosteroid use) or female sex, pregnancy, polycystic ovary syndrome, obesity, use of oral contraceptives suggests a hormonal effect in the etiopathogenesis. A neuroendocrine effect has been suggested to cause increased production of CSF by stimulation of mineralocorticoid receptors in the epithelial cells of the choroid plexus (35). This hypothesis may be illustrative in patients with hyperaldosteronism, obesity, and hypercortisolism, and in patients who are on recombinant growth hormone treatment; there was no evidence of increased production of CSF in patients without identified causes (36).

The argument that the decrease in venous drainage causes IIH remains unclear in the etiopathogenesis. Non-obstructive venous stenosis can be descriptive in head trauma, otitis media or other prothrombotic diseases (such as Behçet's disease, systemic lupus erythematosus, Factor V Leiden mutation, antithrombin III deficiency, and hormone therapies). However, the frequent observation of comorbid prothrombotic factors such as obesity, female sex, and pregnancy complicates the clarification of this situation (32).

It was also suggested that transverse sinus stenosis in IIH might result from increased intracranial pressure rather than being a cause of the disease (37). Transverse sinus asymmetry and unilateral hypoplasia are considered normal variants in patients with normal intracranial pressure. Anatomic studies have shown that stenosis is due to trabeculae, septa or hypertrophic granulomas (38). The presence of transverse sinus stenosis following normalization of CSF pressure in patients with IIH (39), and the absence of correlation between visual field loss and the degree of stenosis (34) suggest that stenosis is a result rather than an etiologic factor.

The perioptic subarachnoid space differs from other subarachnoid spaces owing to its "cul-de-sac" anatomy and trabeculated structure (Figure 4). The optic nerve, being an extended bunch of dura-covered white matter into the orbit rather than a histologically true cranial nerve, is also in a distinctive position. The unique anatomy of the optic nerve results in direct vulnerability of the nerve in the event of intracranial spaceoccupying lesions, IIH, infectious and inflammatory central nervous system diseases (40).

Contrast-enhanced computerized cisternography in 3 patients with $\mathrm{IIH}$ revealed absence of enhancement in the perioptic subarachnoid space indicating the disruption of free circulation of CSF in subarachnoid space and thus led to the term; optic nerve 
compartment syndrome (ONCS). In these 3 patients, the CSF by LP and the CSF in the optic nerve sheath was compared when performing optic nerve sheath fenestration (ONSF) for treatment. "Lipocalin-like prostaglandin D synthase (L-PGDS)" levels in the optic nerve sheath were found 2 to 7 times higher than CSF with LP according to the severity of the disease. L-PGDS is a brainderived protein and is homogeneous in CSF. This study supports ONCS due to decreased excretion or increased production of L-PGDS in the perioptic subarachnoid space (41). Distention of the perioptic subarachnoid space, flattening of the posterior sclera, protrusion of optic nerve papillae into vitreous and even empty sella may be considered as neuroimaging findings of optic nerve compartment syndrome.

\section{Treatment}

Although the etiology has not been clarified in $\mathrm{IIH}$, there are many treatment methods. The aim of medical treatment is to reduce CSF production or increase its drainage. Losing weight along with medical treatment was shown to have positive effects on headache, visual field, and papilledema $(42,43)$. Several surgical techniques have been described in refractory patients. Treatment should be determined according to the patient and course of the disease. The goal of treatment should be preventing vision loss and headache by reducing intracranial pressure.

Acetazolamide, which is a carbonic anhydrase inhibitor that reduces CSF production from the choroid plexus, is one of the main drugs. One to four $\mathrm{g} /$ day acetazolamide can be used at divided doses, two times a day or three times a day. Although this drug has positive effects on papilledema and vision, it is believed to have a limited effect on the management of headaches (44). Paresthesias due to hyponatremia and hypokalemia are the most common adverse effects. In such a situation, treatment can be continued with potassium supplementation and close monitoring in the absence of other organ dysfunction. Adverse effects such as rash, crystalluria, kidney stones, bone marrow depression, thrombocytopenia, and hemolytic anemia require discontinuation of the treatment.

Topiramate, also used in the treatment of migraine, is a weak carbonic anhydrase inhibitor and is preferred due to its weight loss side effect $(45,46)$. Topiramate has been demonstrated to be effective in the treatment of IIH and should be used in patients who are refractory to acetazolamide or who cannot use the drug due to adverse effects $(46,47)$. Daily 100 to $150 \mathrm{mg}$ topiramate dosages that were initiated at $50 \mathrm{mg}$ daily divided dosages were reported effective (46).

There is no evidence that steroids are useful in the treatment of IIH. They should not be recommended because of adverse effects such as weight gain and venous stasis, and their potential to cause secondary intracranial hypertension (48). Drugs such as furosemide and mannitol have intracranial pressure reducing effects without a clear mechanism $(24,49)$.

Diagnostic lumbar puncture (LP) may help to relieve symptoms by decreasing CSF pressure. In addition to medical treatment, LP may be performed at regular intervals depending on the patients' symptoms (48). However, recurrent LP is not usually recommended due to infection risks and uncomfortable situations. A lumbo/ ventriculo-peritoneal (LPe/VP) shunt should be considered as an option in patients who benefit from successive LPs, but not from medical treatment. Shunt operation does not provide remission in all patients and may cause surgical complications such as shunt dysfunction and infection. Patients who have benefited from surgery may again become symptomatic in approximately 2 years even though their shunts are functional $(50,51,52)$. In a study by Rosenberg et al. (53), the authors found that the mean time to LPe shunt revision was 9 months and that $64 \%$ of all LPe shunts were replaced within 6 months in patients with $\mathrm{IIH}$. While the most frequent complication of LPe shunt in IIH is shunt obstruction, the second most common complication is secondary intracranial hypotension due to CSF overshunting $(53,54,55,56,57)$. Despite these, it is recommended as a first-line treatment in patients with headache and visual impairment (54).

VP shunts are known to have less risk of complications and revision rates compared with $\mathrm{LPe}$ shunts $(52,58)$. A sufficient ventricular width is necessary for successful shunting. Framed or frameless stereotactic shunting in the presence of slit ventricles, as frequently seen in IIH, has less risk of complications $(59,60)$. Secondary intracranial hypotension due to overshunting is observed less in VP shunts with the use of programmable valves $(52,58,61)$. McGirt et al. (58) reported that VP shunting relieved headache in up to $95 \%$ of patients with headache. However, headache reoccur in $20 \%$ and $48 \%$ of patients within 12 and 36 months, respectively, despite a functional shunt (58). In addition to all these, it should be kept in mind that shunts are not helpful in patients without papilledema and associated long-term symptoms $(58,61)$. Optic nerve compartment syndrome should be suspected in patients who partially benefited or did not benefit from shunt surgery.

ONSF is performed by cutting a dural and arachnoid window in the optic nerve sheath. For many years, it was performed by ophthalmologists using different techniques, mainly through orbitotomy. Associating adjacent compartments surrounding the optic nerve allows local decompression of the nerve. The improvement in vision in ONSF $(80 \%)$ was shown to be better compared with other methods (38.7-47\%) (62). On the other hand, this method is also associated with serious complications. Iris sphincter paresis, central retinal artery occlusion, and accommodation paresis are some of these serious complications $(63,64,65,66,67,68,69)$. The papilledema and visual field were shown to improve even in the contralateral eye in patients with unilateral surgery (70).

In order to eliminate the risk of these serious complications, an endoscopic endonasal approach, which is a more physiologic and a minimally invasive method, was developed by neurosurgeons as an alternative to orbitotomy. Although some patients underwent ONSF with the endoscopic endonasal method $(71,72)$, there are also patients who received optic decompression without ONSF $(73,74)$. Endoscopic endonasal procedures may be unilateral $(71,73,74)$ or bilateral (72). Endoscopic unilateral optic decompression is a newly defined method with low complication rates, and has positive effects on headache, papilledema, and visual field (73). The papilledema and visual field were shown to improve even in the contralateral eye in patients with unilateral surgery (73).

Transverse venous sinus stenting is another defined invasive procedure in $\mathrm{IIH}$, but it is questionable as to whether the stenosis is a cause or a result (34). Therefore, the contributions of restoring venous sinus flow with this invasive method are controversial. 
Research in this field is extremely new. Studies including a limited number of cases were published and successful results were reported $(75,76)$. The long-term results of this method are unknown and some authors believe that resolving venous sinus stenosis will not provide a clinical benefit to patients $(77,78,79)$.

Invasive procedures should be scheduled immediately in the progressive vision loss despite medical treatment. In the literature, it was stated that ONSF might be preferred in patients with evident papilledema and vision loss, and VP and LPe shunts might be preferred in patients with evident headache $(50,51)$. However, this should not be perceived as a rule, and the treatment should be decided according to the case considering new surgical methods.

Weight gain and hormonal alterations may trigger the disease during pregnancy or may worsen the existing disease. Venous sinus thrombosis, which is commonly observed in pregnancy, must be excluded. The use of category $\mathrm{C}$ drugs, acetazolamide and topiramate, is not recommended in the first trimester. LP at regular intervals may be choice in these patients. Based on the fact that the growing uterus may cause shunt obstruction, ONSF should be preferred in patients who require surgical treatment.

Headache may continue after CSF pressure is normalized. In such cases, depression, anxiety, and any other types of accompanying headaches such as medication-overuse headache, migraine, tension-type headache should be questioned. Primary headaches are frequently seen in young and middle-aged women as IIH and they may worsen due to increased CSF pressure (9). The increase in the headache severity or the change in the headache character may be a symptom of shunt dysfunction or infection. Although the shunt is functional, ophthalmologic follow-up should be continued as IIH may worsen over time.

A different etiology, depending on increased CSF production, may be considered in patients who benefit from CSF-reducing drugs and interventions such as VP and LPe shunts. Decreased CSF drainage may be an etiologic factor in patients who benefit from VP and LPe shunts. Optic nerve compartment syndrome might be suspected in patients who partially benefited or did not benefit from current treatments, but further studies are needed for the elucidation of the etiopathogenesis.

\section{Conclusion}

The etiology of IIH has not yet been elucidated. The signs and symptoms of the disease vary and involve many specialties. A multidisciplinary follow-up is mandatory for all patients. An individualized treatment should be planned and all patients should be closely monitored for visual disturbances. Further scientific studies are needed for better understanding and treatment of IIH.

\section{Ethics}

Peer-review: Externally peer-reviewed.

\section{Authorship Contributions}

Surgical and Medical Practices: A.S., M.O.A., Z.Y., N.H.A., Concept: N.H.A., M.O.A., Design: N.H.A., M.O.A., Data Collection or Processing: N.H.A., M.O.A., Analysis or Interpretation: Z.Y., A.S., M.O.A., N.H.A., Literature Search: N.H.A., M.O.A., Writing: N.H.A.

Conflict of Interest: No conflict of interest was declared by the authors.
Financial Disclosure: The authors declared that this study received no financial support.

\section{References}

1. McCluskey G, Mulholland DA, McCarron P, McCarron MO. Idiopathic Intracranial Hypertension in the Northwest of Northern Ireland: Epidemiology and Clinical Management. Neuroepidemiology 2015;45:3439.

2. Kesler A, Stolovic N, Bluednikov Y, Shohat T. The incidence of idiopathic intracranial hypertension in Israel from 2005 to 2007: results of a nationwide survey. Eur J Neurol 2014;21:1055-1059.

3. Corbett JJ, Savino PJ, Thompson HS, Kansu T, Schatz NJ, Orr LS, Hopson D. Visual loss in pseudotumor cerebri. Follow-up of 57 patients from five to 41 years and a profile of 14 patients with permanent severe visual loss. Archives of Neurology 1982;39:461-474.

4. Friedman DI, Liu GT, Digre KB. Revised diagnostic criteria for the pseudotumor cerebri syndrome in adults and children. Neurology 2013;81:1159-1165.

5. Wall $\mathrm{M}$. The headache profile of idiopathic intracranial hypertension. Cephalalgia 1990;10:331-335.

6. Wall M, George D. Idiopathic intracranial hypertension: a prospective study of 50 patients. Brain 1991;114:155-180.

7. Headache Classification Committee of the International Headache Society (IHS) The International Classification of Headache Disorders, 3rd edition (beta version) Cephalalgia 2013;33:629-808.

8. Headache Classification Subcommittee of the International Headache Society. The International Classification of Headache Disorders: 2nd ed. Cephalalgia 2004;24(Suppl 1):9-160.

9. Ekizoglu E, Baykan B, Orhan EK, Ertas M. The analysis of allodynia in patients with idiopathic intracranial hypertension. Cephalalgia 2012;32:1049-1058.

10. Bono F, Quattrone A. Idiopathic intracranial hypertension without papilloedema in headache sufferers. Cephalalgia 2009;29:594.

11. Marcelis J, Silberstein SD. Idiopathic intracranial hypertension without papilledema. Arch Neurol 1991;48:392-399.

12. Bruce BB, Kedar S, Van Stavern GP, Monaghan D, Acierno MD, Braswell RA, Preechawat P, Corbett JJ, Newman NJ, Biousse V. Idiopathic intracranial hypertension in men. Neurology 2009;72:304-309.

13. Phillips PH. Pediatric pseudotumor cerebri. Int Ophthalmol Clin 2012;52:51-59.

14. Stiebel-Kalish H, Kalish Y, Lusky M, Gaton DD, Ehrlich R, Shuper A. Puberty as a risk factor for less favorable visual outcome in idiopathic intracranial hypertension. Am J Ophthalmol 2006;142:279-283.

15. Zayit-Soudry S, Leibovitch I, Kesler A. Idiopathic intracranial hypertension after 40 years of age: clinical features in 23 patients. Eur J Ophthalmol 2008;18:989-993.

16. Lee AG, Golnik K, Kardon R, Wall M, Eggenberger E, Yedavally S. Sleep apnea and intracranial hypertension in men. Ophthalmology 2002;109:482485 .

17. Bruce BB, Preechawat P, Newman NJ, Lynn MJ, Biousse V. Racial differences in idiopathic intracranial hypertension. Neurology 2008;70:861-867.

18. Szewka AJ, Bruce BB, Newman NJ, Biousse V. Idiopathic intracranial hypertension: relation between obesity and visual outcomes. J Neuroophthalmol 2013;33:4-8.

19. Thambisetty M, Lavin PJ, Newman NJ, Biousse V. Fulminant idiopathic intracranial hypertension. Neurology 2007;68:229-232.

20. Biousse V. Idiopathic intracranial hypertension: diagnosis, monitoring and treatment. Rev Neurol (Paris) 2012;168:673-683.

21. Maxner CE, Freedman MI, Corbett JJ. Asymmetric papilledema and visual loss in pseudotumour cerebri. Can J Neurol Sci 1987;14:593-596.

22. Sher NA, Wirtschafter J, Shapiro SK, See C, Shapiro I. Unilateral papilledema in 'benign' intracranial hypertension (pseudotumor cerebri). JAMA 1983;250:2346-2347.

23. Weisberg LA, Housepian EM, Saur DP. Empty sella syndrome as complication of benign intracranial hypertension. J Neurosurg 1975;43:177-180.

24. Sismanis A, Butts FM, Hughes GB. Objective tinnitus in benign intracranial hypertension: an update. Laryngoscope 1990;100:1152-1155. 
25. Murphy TP. Otologic manifestations of pseudotumour cerebri. J Otolaryngol 1991;20:258-261.

26. Suryadevara AC, Fattal M, Woods CI. Nontraumatic cerebrospinal fluid rhinorrhea as a result of pseudotumour cerebri. Am J Otolaryngol 2007;28:242-246

27. Snyder DA, Frenkel M. An unusual presentation of pseudotumour cerebri. Ann Opthalmol 1979;11:1823-1827.

28. Kutz JW, Hussain IA, Isaacson B, Roland PS. Management of spontaneous cerebrospinal fluid otorrhoea. Laryngoscope 2008;118:2195-2199.

29. Giuseffi V, Wall M, Siegel PZ, Rojas PB. Symptoms and disease associations in idiopathic intracranial hypertension (pseudotumor cerebri): a case-control study. Neurology 1991;41:239-244.

30. Wall M, Friedman DI, Corbett JJ. Revised Diagnostic Criteria For The Pseudotumor Cerebri Syndrome In Adults And Children. Neurology 2014;83;198-200

31. Johnston I, Owler B, Pickard J. The Pseudotumor Cerebri Syndrome: Pseudotumor Cerebri, Idiopathic Intracranial Hypertension, Benign Intracranial Hypertension and Related Conditions. 1st edition, Cambridge University Press; 2007.

32. Skau M, Brennum J, Gjerris F, Jensen R. What is new about idiopathic intracranial hypertension? An updated review of mechanism and treatment. Cephalalgia 2006;26:384-399.

33. Brodsky MC, Vaphiades M. Magnetic resonance imaging in pseudotumor cerebri. Ophthalmology 1998;105:1686-1693.

34. Riggeal BD, Bruce BB, Saindane AM, Ridha MA, Kelly LP, Newman NJ, Biousse V. Clinical course of idiopathic intracranial hypertension with transverse sinus stenosis. Neurology 2013;80:289-295.

35. Salpietro V, Polizzi A, Berte LF, Chimenz R, Chirico V, Manti S, Ferrau V, Salpietro A, Arrigo T, Ruggieri M. Idiopathic intracranial hypertension: a unifying neuroendocrine hypothesis through the adrenal-brain axis. Neuro Endocrinol Lett 2012;33:569-573.

36. Gideon P, Sorensen PS, Thomsen C, Stahlberg F, Gjerris F, Henriksen O. Assessment of CSF dynamics and venous flow in the superior sagittal sinus by MRI in idiopathic intracranial hypertension: a preliminary study. Neuroradiology 1994;36:350-354.

37. King JO, Mitchell PJ, Thomson KR, Tress BM. Manometry combined with cervical puncture in idiopathic intracranial hypertension. Neurology 2002;58:26-30.

38. Strydom MA, Briers N, Bosman MC, Steyn S. The anatomical basis of venographic filling defects of the transverse sinus. Clin Anat 2010;23:153159 .

39. Bono F, Giliberto C, Mastrandrea C, Cristiano D, Lavano A, Fera F, Quattrone A. Transverse sinus stenoses persist after normalization of the CSF pressure in IIH. Neurology 2005;65:1090-1093.

40. Killer HE, Jaggi GP, Flammer J, Miller NR, Huber A. The optic nerve: a new window into cerebrospinal fluid composition? Brain 2006;129:1027-1030.

41. Killer HE, Jaggi GP, Flammer J, Miller NR, Huber AR, Mironov A. Cerebrospinal fluid dynamics between the intracranial and the subarachnoid space of the optic nerve. Is it always bidirectional? Brain 2007;130:514-520

42. Sinclair AJ, Burdon MA, Nightingale PG, Ball AK, Good P, Matthews TD, Jacks A, Lawden M, Clarke CE, Stewart PM, Walker EA, Tomlinson JW, Rauz S. Low energy diet and intracranial pressure in women with idiopathic intracranial hypertension: prospective cohort study. BMJ 2010;341:c2701.

43. Daniels AB, Liu GT, Volpe NJ, Galetta SL, Moster ML, Newman NJ, Biousse V, Lee AG, Wall M, Kardon R, Acierno MD, Corbett JJ, Maguire MG, Balcer LJ. Profiles of obesity, weight gain, and quality of life in idiopathic intracranial hypertension (pseudotumor cerebri). Am J Ophthalmol 2007;143:635-641.

44. NORDIC Idiopathic Intracranial Hypertension Study Group Writing Committee, Wall M, McDermott MP, Kieburtz KD, Corbett JJ, Feldon SE, Friedman DI, Katz DM, Keltner JL, Schron EB, Kupersmith MJ. Effect of acetazolamide on visual function in patients with idiopathic intracranial hypertension and mild visual loss: the idiopathic intracranial hypertension treatment trial. JAMA 2014;311:1641-1651.

45. Dodgson SJ, Shank RP, Maryanoff BE. Topiramate as an inhibitor of carbonic anhydrase isoenzymes. Epilepsia 2000;41(Suppl 1):S35-39.

46. Celebisoy N, Gokcay F, Sirin H, Akyurekli O. Treatment of idiopathic intracranial hypertension: topiramate vs. acetazolamide, an open label study. Acta Neurol Scand 2007;116:322-327.
47. Smith MB, Griffiths EA, Thompson JE, Wang ES, Wetzler M, Freyer CW. High pseudotumor cerebri incidence in tretinoin and arsenic treated acute promyelocytic leukemia and the role of topiramate after acetazolamide failure. Leuk Res Rep 2014;3:62-66.

48. Stanbury RM, Graham EM. Systemic corticosteroid therapy side effects and their management. Br J Ophthalmol 1998;82:704-708.

49. Thenuwara K, Todd MM, Brian JE Jr. Effect of mannitol and furosemide on plasma osmolality and brain water. Anesthesiology 2002;96:416-421.

50. Sinclair AJ, Kuruvath S, Sen D, Nightingale PG, Burdon MA, Flint G. Is cerebrospinal fluid shunting in idiopathic intracranial hypertension worthwhile? A 10-year review. Cephalalgia 2011;31:1627-1633.

51. Lai LT, Danesh-Meyer HV, Kaye AH. Visual outcomes and headache following interventions for idiopathic intracranial hypertension. J Clin Neurosci 2014;21:1670-1678.

52. McGirt MJ, Woodworth G, Thomas G, Miller N, Williams M, Rigamonti D. Cerebrospinal fluid shunt placement for pseudotumor cerebri associated intractable headache: predictors of treatment response and an analysis of long-term outcomes. J Neurosurg 2004;101:627-632.

53. Rosenberg ML, Corbett JJ, Smith C. Cerebrospinal fluid diversion procedures in pseudotumor cerebri. Neurology 1993;43:1071-1072.

54. Burgett RA, Purvin VA, Kawasaki A. Lumboperitoneal shunting for pseudotumor cerebri. Neurology 1997;49:734-739.

55. Eggenberger ER, Miller NR, Vitale S. Lumboperitoneal shunt for the treatment of pseudotumor cerebri. Neurology 1996;46:1524-1530.

56. Chumas PD, Armstrong DC, Drake JM, Kulkarno AV, Hoffman HJ, Humphreys RP, Rutka JT, Hendrick EB. Tonsillar herniation: the rule rather than the exception after lumboperitoneal shunting in the pediatric population. J Neurosurg 1993;78:568-573.

57. Chumas PD, Kulkarni AV, Drake JM, Hoffman HJ, Humphreys RP, Rutka JT. Lumboperitoneal shunting: a retrospective study in the pediatric population. Neurosurgery 1993;32:376-383.

58. McGirt M, Woodworth G, Thomas G, Miller NR, Williams M, Rigamonti D. Frameless stereotactic ventriculoperitoneal shunting for pseudotumor cerebri: an outcomes comparison versus lumboperitoneal shunting. Neurosurgery 2004;55:458-459.

59. Woodworth GF, McGirt MJ, Elfert P, Sciubba DM, Rigamonti D. Frameless stereotactic ventricular shunt placement for idiopathic intracranial hypertension. Stereotact Funct Neurosurg 2005;83:12-16.

60. Abu-Serieh B, Ghassempour K, Duprez T, Raftopoulos C. Stereotactic ventriculoperitoneal shunting for refractory idiopathic intracranial hypertension. Neurosurgery 2007;60:1039-1044.

61. McGirt MJ, Woodworth G, Thomas G, Miller N, Williams M, Rigamonti D: Cerebrospinal fluid shunt placement for pseudotumor cerebri-associated intractable headache: predictors of treatment response and an analysis of long-term outcomes. J Neurosurg 2004; 101:627-632.

62. Feldon SE. Visual outcomes comparing surgical techniques for management of severe idiopathic intracranial hypertension. Neurosurg Focus 2007;23:E6.

63. Banta JT, Farris BK. Pseudotumor cerebri and optic nerve sheath decompression. Ophthalmology 2000;107:1907-1912.

64. Bourman ND, Spoor TC, Ramocki JM. Optic nerve sheath decompression for pseudotumor cerebri. Arch Ophthalmol 1988;106:1378-1383.

65. Brodsky MC, Rettele GA. Protracted postsurgical blindness with visual recovery following optic nerve sheath fenestration. Arch Ophthalmol 1997; 115:1473-1474

66. Corbett JJ, Nerad JA, Tse D, Anderson RL. Result of optic nerve sheath fenestration for pseudotumor cerebri. The lateral orbitotomy approach. Arch Ophthalmol 1988;106:1391-1397.

67. Plotnik JL, Kosmorsky GS. Operative complications of optic nerve sheath decompression. Ophthalmology 1993;100:683-690.

68. Smith KH, Wilkinson JT, Brindley GO. Combined third and sixth nerve paresis following optic nerve sheath fenestration. J Clin Neuroophthalmol 1992;12:85-87.

69. Spoor TC, MacHenry JG. Long term effectiveness of optic nerve sheath decompression for pseudotumor cerebri. Ophthalmology 1993;111:632-635.

70. Sergott RC, Savino PJ, Bosley TM. Modified optic nerve sheath decompression provides long-term visual improvement for pseudotumor cerebri. Arch Ophthalmol 1998;106:1384-1390. 
71. Gupta AK, Rajini Ganth MG, Gupta A. Modified endoscopic optic nerve decompression in idiopathic intracranial hypertension. J Laryngol Otol 2003;117:501-502.

72. Koc K, Anik I, Altintas O, Ceylan S. Endoscopic optic nerve decompression for idiopathic intracranial hypertension in two cases. Case report. Minim Invas Neurosurg 2008;51:72-75.

73. Sencer A, Akcakaya MO, Basaran B, Yorukoglu AG, Aydoseli A, Aras Y, Sencan F, Satana B, Aslan I, Unal OF, Izgi N, Canbolat A. Unilateral endoscopic optic nerve decompression for idiopathic intracranial hypertension: a series of 10 patients. World Neurosurg 2014;82:745-750.

74. Patrocinio JA, Patrocinio LG, Junior FB, da Cunha AR. Endoscopic decompression of the optic nerve in pseudotumor cerebri. Auris Nasus Larynx 2005;32:199-203.

75. Ahmed RM, Wilkinson M, Parker GD, Thurtell MJ, Macdonald J, McCluskey PJ, Allan R, Dunne V, Hanlon M, Owler BK, Halmagyi GM. Transverse sinus stenting for idiopathic intracranial hypertension: a review of 52 patients and of model predictions. AJNR Am J Neuroradiol 2011;32:1408-1414.
76. Kumpe DA, Bennett JL, Seinfeld J, Pelak VS, Chawla A, Tierney M. Dural sinus stent placement for idiopathic intracranial hypertension. J Neurosurg 2012;116:538-548.

77. Karahalios D, Rekate HL, Khayata MH, Apostolides PJ. Elevated intracranial venous pressure as a universal mechanism in pseudotumor cerebri of varying etiologies. Neurology 1996;46:198-202.

78. Rohr A, Dörner L, Stingele R, Buhl R, Alfke K, Jansen O. Reversibility of venous sinus obstruction in idiopathic intracranial hypertension. Am J Neuroradiol 2007;28:656-659.

79. Rohr A, Bindeballe J, Riedel C, van Baalen A, Bartsch T, Doerner L, Jansen O. The entire dural sinus tree is compressed in patients with idiopathic intracranial hypertension: a longitudinal, volumetric magnetic resonance imaging study. Neuroradiology 2012;54:25-33. 